\title{
Náruživost, koordinace a kontrolované užívání drog'
}

\author{
Addiction, Coordination, and Controlled Drug Use \\ Jan Morávek a Jiří Kabele
}

\begin{abstract}
When addiction gets out of control, addicts lose accountability; stigmatization and exclusion from conventional roles often ensue. Many family members are trapped in uneven, dysfunctional relationships. We reinterpret such effects of addiction based on Kabele's justice theory of coordination (2007) as a process in which private making of justice is disabled and the mechanism of construction of reality breaks down. Drug policies fail to eliminate addiction as such. Prohibitionist policies worsen the breakdown of reality construction, while medical and social rehabilitative policies have limited resources to remedy it. Thus, we hypothesize that in order to minimize unintended effects of addiction, policies best intervene indirectly: focus on addict accountability and inclusion in conventional roles; and foster conditions for private coping with addiction. We recommend a strategy that embraces controlled drug use or, more generally, the art of controlling one's addictions.
\end{abstract}

KEYWORDS addiction, controlled drug use, drug policy, justice theory of coordination

\section{Úvod}

Objali jsme se a sedli si ke stolku u okna. Do očí se mi dívat nemohl. Žádná omluva za to, že přišel pozdě. Zeptal se, jak se mám a jak se mají sestřička a bráška. Ohýbal slámku a zase ji narovnával a nervózně se houpal na židli. Prsty se mu třásly, svíral čelisti a skř́pal zuby. Veškeré dotazy předem vyřídil prohlášením: „Mám se. Skvěle. Dělám, co potřebuji dělat, poprvé v životě zodpovídám sám za sebe.“ Zeptal jsem se, jestli je připraven přestat, vrátit se mezi živé, na což odpověděl: „Nezačínej s tím.“ Když jsem řekl, že Jasperovi a Daisy se po něm stýská, odsekl: „Na to nemám. Nesnaž se hrát na city.“ Načež vyprázdnil svůj hrnek kávy, pohladil se po bříšku. Sledoval jsem, jak vstává a odchází (Sheff 2005: 6).

Nik je mladý muž žijící v americkém Oregonu, který miluje svou rodinu. Má ovšem také zálibu v metamfetaminu (českému čtenáři známějším pod názvem pervitin). Často svým blízkým lže do očí a při přepadových návštěvách rodiny krade. Sheffova (2008) autobiografie popisuje, jak autor svého syna opakovaně posílá na léčení a ve vztahu k němu se zmítá v cyklu obav a úlevy, důvěry, podrazů, přijetí a zavržení. Nik vystupuje vůči otci tu jako agresor, jednající bez výčitek, tu jako kající se prosebník. Obě role strrídá bez varování, a tak se

Sociální studia. Fakulta sociálních studií Masarykovy univerzity, 1/2010. S. 93-114. ISSN 1214-813X.

Tento článek byl podpořen z výzkumného záměru FSV UK „Rozvoj české společnosti v EU: výzvy a rizika“, MSM 0021620841. Děkujeme dvěma anonymním recenzentům za cenné připomínky. 
pro svou rodinu stává chronicky nevyzpytatelným a zklamávajícím partnerem. Rodiče jeho chování musejí snášet, nechtějí-li o syna přijít, ovšem druzí - přátelé a pracovníci institucí, $\mathrm{s}$ nimiž přichází do styku - $\mathrm{k}$ takové toleranci nuceni nejsou, a proto se Nikovy sociální sítě zúžily a změnilo se jejich obsazení.

Nikova náruživost v nepravidelném cyklu torpéduje mechanismus sociálního konstruování sociální reality (dále jen konstruování reality). Výsledkem je nestabilní svět poznamenaný vzájemným poškozováním, znevýhodňováním a ztrátou horizontů budoucnosti všech účastníků. Proto může být pro výklad dopadů jeho náruživosti využita Kabeleho (2007) spravedlnostní teorie koordinace. Klíčovou roli v tomto výkladu sehrává samotná náruživost.

Spravedlnostní teorie koordinace (oddíl I) pojímá koordinaci jednotlivců mezi sebou a organizacemi jako zdroj i nástroj utváření sociálních světů garantující jejich členitost, rozmanitost, přizpůsobivou proměnlivost, ale také nadějnost, spojovanou s horizonty budoucnosti jednotlivých členů. Tato koordinace se z celé řady důvodů - nedostatek či asymetrie informací, novost úloh, stranickost a oportunismus účastníků atd. - může dostávat do stavu, kdy tyto funkce neplní. Prokazuje ovšem také obdivuhodnou schopnost regenerace svých funkcí. Jindy se lidé a organizace naopak rozcházejí, aniž by to vedlo k závažným důsledkům. Všechny tyto obdivuhodné vlastnosti koordinace - konstruktivnost, namířenost do budoucnosti, schopnost regenerace funkcí, v moderní době i právo na svobodný odchod - se dle spravedlnostní teorie koordinace rodí ze strategického vyvažování voleb v rámci každodenního soukromého, povýtce neviditelného zjednávání spravedlnosti. Díky tomuto zjednávání všichni účastníci vědí, že když chtějí něčeho společně dosáhnout, musejí se vystavovat vlivu ostatních účastníků, kteří chrání své zájmy a práva. Avšak náruživost v nepravidelných cyklech znehodnocuje platnost tohoto principu. Říkáme-li, že torpéduje konstruování reality, máme na mysli, že sama koordinace se virtualizuje a stává svou karikaturou, ztrácí svou funkčnost: konstruktivnost, namířenost do budoucnosti, schopnost regenerace a svobodnost. Viditelnými důsledky takového selhávání koordinace je „vypadávání“ účastníků z konvenčních rolí, signalizované obcházením pravidel a neplněním závazků. Nekončíli takový postupující deviantní vývoj účinným sociálním vylučováním náruživce, propadá se realita jeho života i života blízkých osob do neřešitelných chronických konfliktů, které mohou končit i úplnou dezorganizací jejich světů.

Za obzvlášt' intenzivně studovanou a regulovanou oblast náruživosti považujeme užívání drog. V oddíle II proto přibližujeme problémy zhroucení konstrukce reality v důsledku nezvládané náruživosti pomocí známých medicínských pojmů závislosti a zneužívání (škodlivého užívání) drog. Zároveň nabízíme jiný úhel pohledu na tyto jevy. Vytyčujeme rozdíl mezi kontrolujícími a nekontrolujícími se uživateli drog, a to podle jejich dynamické ne/začleněnosti do konvenčních sociálních rolí. Nezvládaná náruživost souvisí s výpadkem z těchto rolí. Nejvíce nespravedlivě na ně doplácejí nerozluční partneři „,náruživcư“ (rodiny). Koordinační napětí v mikro- a mezo-sociální rovině spolu s faktory ceny a nelegálnosti drog mohou vést $\mathrm{k}$ vyloučení, stigmatizaci a vrůstání uživatelů drog do kriminálního prostředí. Po etapě úpadku následuje zpravidla etapa více či méně úspěšného, avšak jen dočasného boje s drogou.

S nekontrolovaným užíváním drog je spojena široká škála škod a nespravedlností. Tyto společenské dopady - vedle zdravotních - vytváŕejí zakázku pro stát a veřejnou politiku. Zvolená koordinační perspektiva umožňuje teoreticky argumentovat, že snahy veřejné politiky 
namířené proti drogové i jiným náruživostem se snadno mohu stát kontraproduktivními, jestliže budou nepřiměřeně ochromovat soukromé zjednávání spravedlnosti, a tím nezamýšleně posilovat rozvratné působení náruživosti na koordinaci a konstrukci reality. Jak je dnes již uznáváno, nejkřiklavěji se toto úskalí projevuje u prohibice drog, jež všudypř́itomně přispívá k prohlubování koordinačního rozvratu, protože náruživé uživatele stigmatizuje a zatahuje do kriminálního prostředí.

Evropské drogové politiky ve svých složkách trestní represe, léčby i sociální rehabilitace musejí ve svých záměrech usilovat o sociální začleňování uživatelů drog. Přispívají takto v deklaracích k obnově koordinace. Argumentujeme ale tím, že tyto možnosti jsou omezené, a to $\mathrm{z}$ několika důvodů: zasahují sice velké počty nekontrolujících se (stigmatizovaných, sociálně vyloučených) uživatelů drog, ale jen málo těch „hraničních“ (dosud začleněných, ale s rozpadající se kontrolou náruživosti); a na sisyfovskou práci s nekontrolujícími se uživateli často nemají dost prostředků, natožpak aby nabízely východiska i pro jejich partnery a rodiče. Nemohou proto nahradit soukromé zvládání náruživosti, zejména tam, kde nezamýšleně přispívají $\mathrm{k}$ jeho ochromování. Na základě uvedených a dále rozvinutých teoretických argumentů proto doporučujeme, aby veřejné politiky namírené proti náruživostem cíleně posilovaly nejen veřejné, ale také soukromé zjednávání spravedlnosti a braly jejich poměr za kritérium při posuzování přriměřenosti svých zásahů. Jde o to, aby veřejné zjednávání spravedlnosti nevytlačovalo soukromé, $\mathrm{tj}$. aby se dařilo náruživost co nejvíce zvládat $\mathrm{v}$ běžném životě a v neformálních sociálních vazbách (rodina) na mikrosociální úrovni, někdy i za cenu její výběrové tolerance.

V oddíle III pohlížíme na drogovou politiku ve světle našich teoreticky zdůvodněných doporučení. Naznačujeme, jak drogová politika zahrnující „strategii výběrové tolerance náruživosti“ může posilovat soukromé zvládání náruživosti a uvolňovat potenciál koordinace pro méně problémovou konstrukci reality. Tvưrci veřejné politiky by měli přijmout svou bezmoc před faktem, že náruživosti jsou do značné míry součástí života jednotlivců i společnosti. To se promítá do dvou doporučení: 1) v rámci primární prevence vzdělávat a cvičit mladé lidi v umění zvládání náruživostí a 2) ve vhodných případech zpř́ístupňovat dlouhodobě závislým drogy v kontrolované podobě, jako je metadonová substituční terapie. Oba návrhy směřují k posílení koordinace na bázi zjednávání spravedlnosti a předcházejí tomu, aby náruživost torpédovala mechanismus konstruování reality a deformovala druhotně životy náruživců i jejich bližních.

I když v článku pracujeme s řadou pojmů a poznatků z interdisciplinárního pole adiktologie, uplatňujeme záměrně sociologickou perspektivu, nikoli perspektivu sociální práce či medicíny, které se zajímají o způsoby pomoci konkrétním lidem v konkrétních životních situacích. Čtenáři z řad pomáhajících profesí by neměli získat dojem, že jim „mluvíme do řemesla“. Nenabízíme know how pro řešení starých problémů, jako je psychosociální fungování uživatelů drog. Naopak, ze sociologické perspektivy vnímáme náruživost jako společenský jev utvářený mikro-, mezo- a makrosouvislostmi a ptáme se, jak může veřejná politika účinněji řešit problém zhrouceného konstruování reality v souvislosti s náruživostí. Odpověd' může, jak doufáme, poskytnout nový úhel pohledu na otázky drogové politiky. Pokud bude spravedlnostní teorie koordinace inspirativní i pro osoby kontaktně pracující s náruživci, tím lépe. 
Náš argumentační postup spočívá primárně na metodě abdukce (vytváŕíme hypotézy pro pozorované jevy tak, abychom pro ně našli nejlepší možné vysvětlení; Josephson a Josephson 1996). To znamená, že teoretická východiska klademe do nových souvislostí s poznatky řady dosavadních výzkumů a pomocí co možná transparentního myšlenkového postupu vyvozujeme nová zjištění. Tato zjištění proto nemají status empirických faktů, jejichž pravdivostní hodnota by byla zaručena, a jedná se pouze o hypotézy. Na pole empiricky testovatelných hypotéz se dostáváme zejména díky doporučované strategii výběrové tolerance náruživosti.

Jednoho rána přišel Jasper do kuchyně a v rukou držel saténovou krabici, kterou mu kamarád přivezl z Č́iny a ve které měl uloženy svoje úspory ve výši osmi dolarů. Jasper vypadal ohromeně. „Myslím, že mi Nik sebral peníze,“ řekl. Jak vysvětlíte osmiletému dítěti, že je jeho milovaný starší bratr okrádá? (Sheff 2005: 5)

\section{Náruživost, nespravedlnost a koordinace}

Jakou nabídkou je Kabeleho spravedlnostní teorie koordinace (2007), která tvoří jádro jeho duální teorie sociální konstrukce reality (Kabele 1998 a 2005), pro osvětlení problému koordinace v př́ipadě nezvládané náruživosti? Teorie zdůvodňuje, proč je koordinace nákladná a kdy velmi vysoké anebo velmi nízké náklady koordinaci znemožňují, respektive deformují. Náruživost oba tyto efekty kombinuje. Na jedné straně způsobuje, že si lidé nemohou svá práva efektivně chránit, a tak zvyšuje nákladnost koordinace oproti té, kterou známe z výkonu konvenčních rolí, na druhé straně sítem výběru dle koordinační nákladnosti projdou a rutinizují se jen akce charakterizované nízkou koordinační nákladností. Chudé světy náruživců se jeví bezperspektivně nudné a zotročující pro všechny účastníky.

Spravedlnostní teorie koordinace popisuje a vykládá funkci strategického vyvažování scénářů jednání, která optimalizuje síto výběru při konstruování reality. Jednající volí strategicky vyvážené scénáře, které přiměřeně respektují zájmy druhých a předcházejí u nich pocitům zneuznání, křivdy a bezpráví, protože se tak mohou vyhnout odporu druhých při uskutečňování svých záměrů. Teorie říká, že jedině přiměřené respektování zájmu druhých podle pravidel hry činí vzájemnou koordinaci únosně nákladnou a otevírá prostor pro realizaci náročnějších vzájemně výhodných scénářů, těžících z týmového efektu. Naopak opakované zneužívání pravidel a situačních výhod činí jednající nedůvěryhodnými. S puncem nespolehlivé či př́mo kriminální osoby mohou členové společenství další styky s okolím navazovat jen s obtížemi, s většími koordinačními náklady. Jsou neformálně vylučováni, i když jejich členství může zůstávat formálně zachováno. Sami se na vyloučení z běžného života mnohdy podílejí.

Strategicky vyvažovány jsou scénáře, chápané jako cesty z opouštěného manévrovacího prostoru do nového. Při vážení jsou poměřovány podle toho, jak se jimi co do vzájemných výhod a nevýhod mění horizonty budoucnosti. Jednající mobilizuje svoji schopnost empaticky se vmyslet do postavení druhých a vidět situaci jejich očima. Díky tomuto zrcadlení svých počinů může porovnávat svá vlastní zvýhodnění a znevýhodnění se zvýhodněními a znevýhodněními ostatních zúčastněných osob, dokáže předvídat pocity nespravedlnosti i míru 
ochoty anebo odporu druhých vi̊či koordinovanému postupu, tj. dovede kompetentně odhadovat koordinační nákladnost scénáře a upravovat jej tak, aby se nákladnost přiměřeně situaci snížila. Strategické vyvažování propojuje a synchronizuje niternou a meziosobní složku koordinace. Lze ukázat, že toto propojení zajištují klasické „,váhy spravedlnosti““ (Nótári 2005), jejichž ramena se opírají o abstraktní představu o tom, že každá lokální proměna společných záležitostí většího počtu angažovaných osob může být $\mathrm{v}$ závislosti na cestě-scénáŕi: 1) „nestranně“ popsána co do distribuce ne/výhod a z/ne/výhodnění a 2) odpovědně porovnána $\mathrm{s}$ ideální, tj. vyváženou či spravedlivou variantou proměny týchž záležitostí tak, aby byla odpovědně zjištěna bilance externalit vázaných na uskutečnění scénáře. Vznik a uživání „nestranného popisu“ jako etalonu umožňujícího posuzovat stranickost a stanovovat nestrannou spravedlnostní kvalifikaci záležitostí co do bilance externalit je dle zastávané hypotézy vedlejším produktem strategického vyvažování (Kabele 2007).

Síto výběru tvořené koordinačními náklady zahrnuje nejen jednání, ale také struktury (Kabele, v tisku). Vzájemná koordinace voleb stvrzuje a obnovuje respekt jednak k „,pravidlům hry“ - zvyklostem, dohodám a smlouvám a zákonným předpisům - a jednak k tradovaným životním př́běhům bezpráví a obnovy spravedlnosti, jejichž vznik a využití v obou př́ípadech doprovázejí různé formy vyjednávání a zjednávání spravedlnosti mezi účastníky společných záležitostí. K platnosti pravidel přispívá jednak osobní a kolektivní ochrana práv v každodenních situacích (soukromé zjednávání spravedlnosti) a jednak také činnost formálních institucí spravedlnosti - soudů, rozhodčích tribunálů, policie a trestního aparátu (veřejné zjednávání spravedlnosti). Přitom udržování a obnova řádu při konstruování reality podle spravedlnostní teorie koordinace (Kabele 2007) závisí nevyhnutelně na soukromém zjednávání spravedlnosti. Je tomu tak proto, že se může - na rozdíl od zjednávání veřejného - podílet na veškerém běžném rozhodování a jednání každého z nás, kterým společně konstruujeme své světy. Vyvažování relativních zvýhodnění a znevýhodnění je ve spravedlnostní teorii koordinace respektovaným etnoprincipem tohoto rozhodování. Způsobuje, že každodenní aktivity jako metody užívané členy jednotlivých společenství slouží zároveň $\mathrm{k}$ tomu, aby se tytéž aktivity „staly viditelně rozumnými a sdělovatelnými pro všechny praktické záměry jednajících (accountable)“ (Garfinkel 1967: vii) pro koordinující se účastníky. Jednotlivci proto činí volby se zřetelným vztahem ke spravedlnosti v desítkách uvědomovaných a stovkách neuvědomovaných voleb každý den. Státní orgány do těchto mikroprocesů konstruování reality mohou zasahovat jen $\mathrm{v}$ omezeném počtu př́ípadů nespravedlnosti, jen u ,špičky“ ledovce běžných transakcí, která vyčnívá nad hladinou, protože je její spravedlnostní relevance výslovně zdůrazněna nějakou stranou v koordinačně nákladném sporu.

Soukromé a veřejné zjednávání spravedlnosti na sobě navzájem závisejí. Instituce trestní a občanské spravedlnosti - soudy, policie, zastupitelství, arbitráž, vězeňství, probační služba, sociální služby atd. - zabraňují exemplárnímu porušování spravedlnosti. Velkoplošně působí svým vlivem na normotvorné procesy i tím, že na principu precedentu, tj. nepř́mo, pomáhají zjednávat pravidla hry reálně platná $\mathrm{v}$ mikrosvětech. Tato reálná pravidla hry se ovšem mohou značně lišit od pravidel deklarovaných. Je to způsobeno tím, že kvůli strategickému vyvažování zvýhodnění a znevýhodnění jsou vymahatelná jen taková pravidla, která odpovídají skutečně důležitým zájmům hráčů. Řečeno terminologií teorie her jsou to pravidla navozující Nashovu rovnováhu (Hurwicz 1996) na základě strategií, které by rozumní, nikoli nutně 
charakterní hráči svobodně zvolili z nabídky zahrnující všechny možné postupy. Strategické vyvažování voleb účastníků, které se podílí na soukromém zjednávání spravedlnosti v miliardách transakcí prováděných každý den, tak v konečné podobě určuje závaznost a povahu prosazujících se pravidel hry. Vede i k možnosti, že celkové působení institucí trestní a občanské spravedlnosti bude kontraproduktivní. K tomu nutně dochází, jestliže soukromé zjednávání spravedlnosti selhává, protože strategické vyvažování voleb negarantuje uspokojivou vzájemnou koordinaci a zároveň systematicky redukuje objem transakcí odehrávajících se v mikrosvětech anebo do nich vnáší chaos.

V nastíněné perspektivě závislosti veřejného zjednávání spravedlnosti na soukromém (Kabele 2007, 2008) musíme vidět každodenní světy náruživců. V tomto článku argumentujeme, že nezvládaná náruživost se projevuje v setkání s druhými opakovanou ztrátou důvěryhodnosti z důvodu neodpovědného postupu v konvenčních sociálních rolích. Jak ukážeme v následujícím oddíle na problematice drog, nekontrolující se uživatelé poškozují své sociální okolí, v první řadě rodinné př́slušníky, nejrůznějšími necitlivými zásahy, konfliktními postupy či drobnými opomenutími a samozřejmě také zanedbáváním povinností, porušováním smluv, neplněním slibů, podvody, krádežemi apod. Takovéto zhroucení soukromého zjednávání spravedlnosti mezi uživateli drog a ostatními účastníky dění vede tam, kde je to možné, zpravidla k vyloučení uživatelů drog z konvenčních sociálních rolí nebo k jejich dobrovolnému opuštění. Tam, kde to není možné - protože jako v případě Nikovy rodiny jsou tyto role neopustitelné -, se ustavuje deformovaný režim koordinace typický pro na přítomnost zaměřené, nepružné, chudé, beznadějné a nesvobodné světy.

\section{II}

„Žádnou léčbu nepotřebuju.“

„Slíbil jsi to. Málem jsi umřel.“

„Dostal jsem se do průšvihu. To je všechno. Nedělej si starosti. Vzal jsem si ponaučení.“

„Niku, ne. “

„Poslyš, budu v pořádku. Už se toho svinstva nedotknu. Poučil jsem se, jak je pervitin nebezpečný. " (Sheff 2008: 103)

\section{Zneuživání drog, závislost na drogách a kontrola nad jejich užíváním}

Nik v citované situaci nastavuje otci tvář zodpovědného syna, který uznává svůj problém s metamfetaminem a nutnost přestat jej brát. Jeho chování je ale oportunní, neodpovídá slibům. K droze se znovu a znovu vrací a dřívější předsevzetí přicházejí vniveč. Tuto dvojakost v chování drogově náruživých osob se snaží uchopit moderní medicínská teorie. Čtvrté vydání Diagnostické a statistické přiručky duševních chorob (DSM-IV) Americké psychiatrické asociace (APA 1994) uplatňuje pojmy „zneužívání“ (angl. ,abuse“) a „závislosti“. Desáté vydání Mezinárodní klasifikace nemoci Světové zdravotnické organizace (WHO 1990) zase pracuje s pojmy „škodlivého užívání“2 a „,závislosti“. Přibližme si nejprve pojem „zneužívání“. Ten

2 Kódy MKN F10 až F19: poruchy způsobené návykovými látkami. 
neprrímo odkazuje na problémy psychického fungování (sebekontrola, sebevědomí, duševní zdraví apod.) a sociálního fungování (výkon ve škole, výkon v zaměstnání a hodnota na trhu práce, výkon rodičovské role, reputace, styk s kriminálním prostředím). ${ }^{3}$ Ale jak ukazuje rámeček, její jádro netvoří samotná nespolehlivost při výkonu sociálních rolí a interpersonální konflikty, nýbrž působení škod sobě samému a druhým. V tomto ohledu český překlad anglického termínu ,abuse“ jako „zneužívání“ není zcela výstižný. Diagnóza zneužívání drog zřetelně poukazuje na problémy uživatelů, které ve spravedlnostní teorii koordinace považujeme za příznak narušení mechanismu konstruování reality. ${ }^{4}$

\section{Rámeček 1: Operacionalizace zneuživání drog v epidemiologických šetřeních USA}

Respondent je v šetření SAMHSA označen diagnózou zneužívání drogy, pokud splňuje alespoň jedno z následujících čtyř kritérií zneuživání a nebyl v posledním roce diagnostikován jako závislý na této droze:

1. Droga mu způsobovala závažné problémy doma, v zaměstnání, ve škole; např́íklad zanedbávání dětí, pracovní nebo školní absence, odvádění nekvalitní práce v zaměstnání nebo ve škole nebo ztráta zaměstnání či předčasné ukončení studia.

2. Pravidelně užíval drogu a poté se věnoval činnosti, při které se vystavil fyzickému ohrožení.

3. Užívání drogy způsobovalo, že se věnoval činnostem, které jej opakovaně přiváděly do konfliktu se zákonem.

4. V rodině nebo s přáteli měl problémy, které byly pravděpodobně způsobeny uživáním drogy, a on pokračoval v užívání drogy, přestože si uvědomoval, že jsou tyto problémy zapříčiněny užíváním.

Zdroj: SAMHSA 2006 (Dodatek B: Statistické metody a měření).

V diagnóze „drogové závislosti“ se neztrácí jen aspekt škodlivosti, ale také skupinový rozměr, a ona diagnóza se tak týká již jen niterné koordinace. Pojmenovává fakt, že problémové pití a náruživé užívání drog se může stát více než jen neprožretelným chováním vedoucím do nesnází a že se může jednat o poruchu, pro niž jsou nejcharakterističtější dva příznaky: 1) ztráta kontroly nad spotřebou drog a alkoholu a 2) popírání závažnosti a následků této náruživosti.

Pojem „ztráty kontroly“ je založen na přesvědčení, že počáteční užívání drogy vede ke zhoršení schopnosti přestat, což mnozí konstruují jako biologický proces odehrávající se

3 Viz např́íklad MacCoun, Reuter a Schelling 1996: 342-344.

$4 \quad$ V medicínské perspektivě na problémy související s náruživostí bohužel zůstávají mimo zorné pole důvody, proč náruživost tvoří zřejmě nepominutelnou součást života lidí. Máme na mysli obohacující rozměr uživání drog. Drogy momentálně zvyšují výkonnost, uvolňují stres, umožňují uniknout problémům doma, v zaměstnání, ve škole, vyjadřují vzpouru, poskytují vážnost, odbourávají mezilidské bariéry a obstarávají přesažné formativní zážitky - Luckmannovy (1990) „transcendence“. Tento pojem označuje zážitky, které lidi zavádějí mimo situaci „zde a nyní“. Jsou co do přesažnosti odstupňované: formy střední transcendence zahrnují např́iklad empatické představy druhých osob, pravidla hry, ale také duchovní, sexuální anebo kolektivní davové zážitky apod. Zneužívání drogy či obecně nezvládání náruživosti můžeme v tomto smyslu interpretovat jako situaci, kdy je na úrovni individuálního i skupinového života zrušena hranice mezi mimořádným a řádným modem života, mezi všedností a transcendencí. 
uvnitř lidského těla - jako chorobu mozku (Denning, Little a Glickman 2004). Řada empirických výzkumů ovšem dokazuje, že náruživé užívání drog není automaticky spojeno s úplnou ztrátou sebekontroly a s neschopností ovlivnit důsledky užívání drog. Problémy zneuživání drog a závislosti se pohybují na určitém kontinuu od zcela bezproblémového užívání drogy až k úplné ztrátě kontroly nad užívaným množstvím a dopady užívání. Rozsah drogových problémů a kontroly uživatele nad nimi je určen nejen farmakologickým účinkem drogy (drug) a osobností a postoji uživatele (set), ale také způsoby, jak jsou drogy užívány - kdy, s kým, za jakých okolností a v jakém množství (setting). Dále míra kontroly závisí i na zakotvenosti v běžném životě či pevnosti životní struktury a konečně na míře dostupnosti drog. Tzv. kontrolující se uživatelé drog jsou typicky zakotvení v běžných životních rolích, včetně rodiny a zaměstnání, a ohraničují své užívání určitými pravidly ohledně množství, frekvence, prostředí a vhodných psychických stavů (Morávek 2007b).

Stupeň začleněnosti do konvenčních sociálních rolí a kontroly nad užíváním drog dal vzniknout typologii uživatelů metamfetaminu a heroinu. Boeri, Sterk a Elifson (2006) označili čtyři typy: kontrolující se uživatelé, hraniční uživatelé, kriminální uživatelé a marginalizovaní ,junkies“.

Tabulka 1: Typologie uživateli̊ metamfetaminu a heroinu

\begin{tabular}{|l|l|l|l|}
\hline \multirow{2}{*}{\multicolumn{2}{|c|}{}} & \multicolumn{2}{|l|}{ Začleněnost do konvenčních sociálních rolí } \\
\cline { 3 - 4 } \multicolumn{2}{|c|}{} & Vysoká & Nízḱ \\
\hline \multirow{2}{*}{$\begin{array}{l}\text { Kontrola nad } \\
\text { uživáním drog }\end{array}$} & Vysoká & Kontrolující se uživatelé & Kriminální uživatelé \\
\cline { 2 - 4 } & Nízká & Hraniční uživatelé & Junkies \\
\hline
\end{tabular}

Zdroj: Boeri, Sterk a Elifson (2006).

Kontrolující se uživatelé heroinu a metamfetaminu se vyznačují stabilní kontrolou nad spotřebou drog a udržováním konvenčních sociálních rolí v zaměstnání, v rodině, ve vztahu k místním organizacím apod. Hraniční uživatelé si udržují konvenční sociální role, ale přestávají zvládat svoji drogovou náruživost - tento stav je dlouhodobě neudržitelný. Z role hraničního uživatele vede cesta zpět ke kontrolovanému užívání, do léčby a/nebo abstinence nebo směrem k roli uživatele kriminálního. Kriminální uživatelé heroinu a metamfetaminu (v originále hustlers) si již nesou stigma drogově závislých a nespolehlivých jedinců. Ztráta nebo vzdání se zaměstnání je vede k nelegálním způsobům obživy, jako je organizovaná majetková kriminalita, obchodování s drogami nebo sexuální práce. Svoji spotřebu drog udržují pod kontrolou do té míry, aby byli schopni obživy a obstarání drog v těchto nových rolích. Konečně ,junkies“ se vyznačují absencí legálních i nelegálních způsobů obživy, sociální marginalizací a ztrátou kontroly nad spotřebou drog. Manévrují chaoticky, od dávky k dávce, mezi skoupými př́ležitostmi, které jim nabízí drobná kriminalita, žebrota a sociální podpora (Boeri, Sterk a Elifson 2006). 


\section{Nezvládaná drogová náruživost jako koordinační problém}

Hovoříme-li v tomto článku o „,nekontrolujících se uživatelích drog“ nebo „nezvládané drogové náruživosti“, máme na mysli uživatele typu kriminálního uživatele nebo typu ,junkie“. Pojd’me se nyní podívat blíže na problémy spravedlnosti, které souvisejí s životem takovýchto uživatelů drog ve společnosti. Nejprve si ale zopakujme, že podle spravedlnostní teorie koordinace (Kabele 2007) je spravedlnost, a tím i žitá přítomnost řádu, soukromě zjednávána v každodenních transakcích následujícím způsobem: když se jedinec chce s ostatními koordinovat, je nucen porovnávat alternativní scénáře svého jednání nejen z hlediska předpokládaných výhod a nevýhod pro sebe sama, ale prostřednictvím schopnosti empatie také podle výhod a nevýhod pro ostatní aktéry. Kdyby aktér, v našem př́padě nekontrolující se uživatel drog, tyto cizí zájmy nerespektoval, musí očekávat odpor, protože ostatní aktéři se budou cítit znevýhodnění a budou vyžadovat zjednání nápravy, anebo se s ním jednoduše odmítnou stýkat. V této každodenní vzájemné koordinaci se obnovuje a stvrzuje řád tehdy, když jednotlivci preventivně anebo kvůli tlaku druhých vyvažují své scénáře jednání způsobem kompenzujícím vzájemná zvýhodnění i znevýhodnění.

Jak víme, u náruživých uživatelů drog se může z řady důvodů zhoršit niterná koordinace voleb. Kleiman (1997) upozorňuje na následující mechanismy, jak drogy omezují výkon účelové racionality u jedince: přínosy intoxikace jsou uživatelům zjevné a jsou okamžité, zatímco náklady často zůstávají skryté a odložené. Intoxikace může vést k selhání sebekontroly po dobu, kdy je uživatel pod vlivem drogy. To snižuje schopnost uživatelů dostát závazkům a ochotu podvolit se tlaku druhých, jehož výkon je součástí ,pravidel hry“ anebo zapojuje do hry místně ustavené neformální instituce sociální kontroly. Závislost je pak prožívána jako selhání sebekontroly nad užíváním drog jako takovým, a opakované návraty k droze prožívají mnozí závislí jako nerozumné chování (tamtéž: 192-193).

Kleimanova zjištění neříkají ovšem „nerozlučným“ partnerům uživatelů drog, kteří nezvládají svou náruživost, nic nového. $\mathrm{V}$ daném teoretickém rámci je můžeme interpretovat tak, že pro jednání uživatelů drog začíná být charakteristický ideální typ hodnotově-racionální akce, zatímco ideální typy racionálně účelové či tradiční akce (Weber 1998 [1905]) se stávají při vysvětlování jejich jednání „nepoužitelnými“. Náruživost staví drogu vysoko v žebříčku prosazujících se hodnot, což se nemusí projevovat v rétorice uživatele, ale odráží se to v jeho volbách. Jeví se jako cyklická posedlost potřebou intoxikovat se, která vylučuje některé alternativní scénáře jednání z posouzení, a tak zužuje a posouvá manévrovací prostor uživatele. Tato „hodnotová přeměna“5 formuje niternou koordinaci, takže vede mnohdy k poškozování nejen sebe sama, ale také druhých osob. Mezi uživatelem a jeho sociálním okolím vzniká řada drobných nespravedlností, malých i větších ztrát, ústrků, nepohodlí, podvodů, zmermomocnění, ponížení a zklamaných nadějí, proti nimž neexistuje obrana. Hlavními obět'mi těchto negativních externalit nekontrolovaného užívání drog jsou často rodinní př́islušníci a partneři.

Za růstem významu drogy v rozhodování náruživého jednotlivce stojí psychologické podmiňování účinkem drogy, určité chemické změny v centrální nervové soustavě, které se mohou projevovat jako bažení nebo abstinenční syndrom, a řada dalších bio-psycho-sociálních jevů, o jejichž interpretaci se v sociálních vědách vedou nekonečné spory. 
Tak jako mnozí lidé v mé situaci jsem se stal závislým na závislosti mého dítěte. Když jsem se jí zabýval, třeba i na úkor mých povinností vůči ženě a ostatním dětem, omlouval jsem si to. Myslel jsem si: jak by rodič nemohl být pohlcen zápasem svého dítěte na život a na smrt? (Sheff 2008: 15)

Výzkumy ukazují, že značné procento uživatelů drog zažívá těžkosti v interakci s druhými, nejčastěji s rodiči (McCambridge a Strang 2004). V rodině vzniká stres v důsledku široké škály zdravotních problémů somatické i psychické povahy. Stigma drogové závislosti může vést ke ztrátě vážnosti a k izolaci nejbližších příbuzných od širší rodiny a přátel. Rodiče uživatelům často dobrovolně nebo nedobrovolně přispívají na náklady pořízení drog (EIU 2002: 10-12). Lockley (1996) uvádí, že důsledky náruživosti často začínají dominovat rodinnému životu a uživatel se stává jediným členem rodiny, který jedná plně, i když nesvéprávně, ve svém vlastním zájmu. Zbytek rodiny se zdráhá narušit rovnováhu a podřizuje se potřebám a požadavkům uživatele. Velleman a kol. (1993) zjistili, že rodiny typicky reagují na drogovou náruživost ve svém středu nekonzistentním přístupem, který osciluje mezi snahou o usmíření a porozumění a tvrdým, odmítavým postojem vůči nespravedlivému jednání. I sami uživatelé prožívají tuto vztahovou nekonzistentnost s nejistotou (Quigley 2002). Podle Guye (2006: 75-76) rodiny uživatelů drog trpí jejich náruživostí ze všech aktérů nejvíce, jsou ovšem často drogovou politikou přehlíženy. Nesou společně s uživatelem stigma závislosti a mezi rodinnými př́slušníky vzniká často velké napětí. Specializované služby poradenství a podpory se však většinou zaměřují výhradně na uživatele jako jednotlivce, a rodiny jako celek k nim nemají prrístup (Copello a Orford 2002: 1361). Rodina se nám proto jeví jako primární místo, kde se uživatel nezvládající svoji náruživost kriticky střetává se sociálním okolím.

Vyústěním napětí mezi nekontrolujícím se uživatelem a sociálním okolím na soukromé úrovni bývá často nejen stigmatizace, ale také redukce vztahů a sociální vyloučení, popř́padě dobrovolný odchod uživatele z domova a původních sociálních kruhů a ze vztahů s institucemi každodenního života (Kuda 2001). ${ }^{6}$ Tato ztráta zázemí má svůj protějšek v začlenění uživatelů do kriminálních sociálních kruhů, které jim také zpravidla usnadňují přístup k nezákonným drogám. K redukci vztahů a vylučování dochází mimovolně i cílevědomě aktivitou uživatelů drog i jejich partnerů. Z důvodu rostoucích finančních nákladů na získávání drogy, ale také nákladů koordinačních, může být pro „hraniční“ náruživé uživatele drog v některém okamžiku výhodné odpoutat se od rodiny a konvenčních sociálních rolí a stát se uživateli kriminálními, protože to je nejvýhodnější strategie, jak si drogy maximálně užít, anebo jediná možná strategie, jak získat př́isun drog pro zamezení abstinenčnímu syndromu. Pro poškozované partnery se redukce vztahů a vylučování - omezení a přerušení vazeb s uživatelem drog - stávají naopak přitažlivými proto, že nejlepší ochranou vlastních práv před břemeny soužití s uživateli drog je nemít s nimi - třeba i jen načas - nic společného.

Stigmatizace, redukce vztahů a sociální vylučování bývají značnou měrou vyvolávány tím, že uživatelé drog se „,nemohou“ držet strategického vyvažování a nepokrytě druhé ve vzájemné koordinaci znevýhodňují. Nerespektují jejich tlaky, hrozby a sankce a tyto jejich nevyslyšené hrozby a sankce naopak problém eskalují a „dláždí cestu“ do kriminálních sociálních kruhů. Tak je v každodenních transakcích uživatelů a blízkých osob dovršeno ochromení

6 U jiných uživatelů může být naopak hrozba stigmatizace a sociálního vyloučení dostatečným motivem ke kontrole či vzdání se náruživosti. 
soukromého zjednávání spravedlnosti. Blízké osoby ztrácejí veškerý vliv na uživatele a droga se jim jeví jako svévolný aktér určující stejně tak život uživatele jako jich samotných.

\section{Škody z užívání drog jako nespravedlnosti}

Jak jsme naznačili, drogovou náruživost uvádí do souvislosti se zjednáváním spravedlnosti nejen fakt, že nekontrolující se uživatelé drog se vůči svému sociálnímu okolí dopouštějí ve významně větší míře přečinů a zločinů, ale také skutečnost, že jsou neurčitým, ale zato vytrvalým zdrojem negativních externalit pro osoby vstupující s nimi do styku. Vidíme, že v důsledku selhávání vazby mezi niternou a meziosobní koordinací nekontrolujících se uživatelů drog široká škála selhání a škod deformuje především jejich „nerozlučné“ vztahy rodinné a partnerské. Zatím nejúplnější přehled škod souvisejících s užíváním drog a drogovou politikou zpracovali MacCoun, Reuter a Schelling (1996). Vybrali jsme některé typy škod, které se projevují ve vztazích uživatelů drog s dalšími osobami:

\section{Tabulka 2: Škody a selhání souvisejícís drogovou náruživostí (výňatek)}

\begin{tabular}{|l|c|c|c|}
\hline \multirow{2}{*}{ Druh škody } & \multicolumn{2}{l|}{ Hlavní zdroj škody } \\
\cline { 2 - 4 } & $\begin{array}{l}\text { Ǔ̌́vání } \\
\text { drog }\end{array}$ & $\begin{array}{l}\text { Nelegálnost } \\
\text { drog }\end{array}$ & $\begin{array}{c}\text { Vynucování } \\
\text { práva }\end{array}$ \\
\hline $\begin{array}{l}\text { Dopady užívání v těhotenství a mateřství } \\
\text { na novorozence }\end{array}$ & $\mathrm{X}$ & & \\
\hline $\begin{array}{l}\text { Násilí vyvolané psychofaramakologickými účinky } \\
\text { drogy }\end{array}$ & $\mathrm{X}$ & & \\
\hline Špatný výkon rodičovských rolí, zneužívání dětí & $\mathrm{X}$ & & \\
\hline Snížená výkonnost ve škole, zaměstnání & $\mathrm{X}$ & & \\
\hline Ovlivnění způsobů užívání drog u dalších osob & $\mathrm{X}$ & & \\
\hline Nehody na silnicích, na pracovišti apod. & $\mathrm{X}$ & & \\
\hline Přenos HIV a jiných infekčních chorob & $\mathrm{X}$ & $\mathrm{X}$ & \\
\hline Poškození sebeúcty, dobré pověsti & $\mathrm{X}$ & $\mathrm{X}$ & \\
\hline Zhoršení zaměstnatelnosti & $\mathrm{X}$ & $\mathrm{X}$ & \\
\hline Majetková a loupežná kriminalita & $\mathrm{X}$ & & \\
\hline Násilí vyvolané ekonomickými motivy & & & $\mathrm{X}$ \\
\hline
\end{tabular}

Zdroj: MacCoun, Reuter a Schelling (1996).

Téměř padesátka problémů je roztříděna do kategorií zdraví, sociální a ekonomické fungování, bezpečnost a veřejný pořádek a trestní spravedlnost. U každého problému je identifikován okruh obětí (uživatelé, prodejci drog, blízcí uživatelů, zaměstnavatelé, sousedé, společnost) a systémový zdroj (užívání drog, nelegální status drog, vynucování práva). Faktor užívání drog převažuje například u zanedbávání péče o děti nebo nedostatečného pracovního výkonu. Nelegálnost drog má velký podíl na problémech spojených se sociálním vyloučením 
uživatelů, jako je zhoršení pověsti a zaměstnatelnosti. Vynucování práva se typicky projevuje ve zvýšených cenách drog, což zhoršuje dopady majetkové kriminality závislých (nezamýšleným důsledkům nelegálnosti a vynucování práva se věnujeme níže).

V přehledu ovšem chybí škoda ústřední, spočívající v tom, že nezvládaná drogová náruživost soustavně deformuje vzájemnou koordinaci mezi uživatelem a jeho okolím, a znemožňuje tak obnovu a stvrzování řádu. Vede kvůli selhávání soukromého zjednávání spravedlnosti ke vzniku a reprodukci nikým nechtěné sociální reality s vyšší úrovní koordinačních nákladů a s rozsáhlým narušováním a nenaplňováním práv třetích osob. Jádro problému tkví v ne/fungování sociálních světů zahrnujících uživatele drog, z něhož prímo či nepřímo pochází většina škod problematizovaných v drogové politice.

\section{Kriminalizace, medikalizace a welfarizace drogové náruživosti}

Stát je ústavně zavázán chránit občanská a sociální práva občanů (například právo na ochranu zdraví, právo na ochranu rodičovství a rodiny, právo na ochranu majetku), včetně uživatelů drog samých, před následky nezvládání drogové náruživosti. Proto důležitou součást drogových politik tvoří nejen opatření vykonávaná institucemi kriminální spravedlnosti (represe), ale také opatření prevence, léčby a sociální péče. Medikalizace a welfarizace užíání drog, doplňující jeho morální odsuzování a kriminalizaci, významně rozšiřuje pole boje státu s drogovou nezdrženlivostí. Ale účinek popisovaných strategií na soukromé zjednávání spravedlnosti může být dvojznačný. Navíc medikalizace spolu s welfarizací veřejnost i odbornou obec politicky polarizují. Nepanuje shoda, zda je správné rozvíjet solidárnější sociální politiku vůči alkoholikům a uživatelům drog. Přednosti medikalizace a welfarizace v očích jedněch (Earleywine 2002: 34, Gusfield 1989: 433) jsou morální kapitulací v očích druhých, jimž vadí odměňování uživatelů-pachatelů, považovaných za skutečné viníky problému (Husak 2004, Morávek 2007c).

Represe nabídky (popřípadě i užívání) drog pomáhá zmírňovat drogový problém mimo jiné tím, že snižuje dostupnost drog, činí jejich užívání nepohodlným a symbolicky potvrzuje nemravnost drogové náruživosti. Trestní represe spojená s nabídkou léčby a sociální rehabilitací7 - vnímáme-li ji jako formu veřejného zjednávání spravedlnosti - působí dílem i jako nástroj obnovy sociálního fungování (bývalých) uživatelů drog v konvenčních rolích, ale zároveň může vést, jak naznačuje výše uvedená tabulka 2 , i k nežádoucím důsledkům. Nejenže svým tlakem na zvýšení ceny drog zhoršuje majetkovou kriminalitu a vedlejší projevy nezákonné distribuce, ale také vytvárí násilí na drogových trzích a přispívá ke stigmatizaci uživatelů. Těmito způsoby všudypřítomně přispívá k prohlubování koordinačního rozvratu, a tím

\footnotetext{
Nesčetní autoři (např́iklad Hartnoll 2005, Bertram a kol. 1996) poukázali na skutečnost, že potrestání sociálně vyloučených uživatelů drog - není-li doprovázeno dalšími opatřeními - neřeší prř́činy jejich problémů, a naopak prohlubuje jejich sociální stigmatizaci a hmotnou nouzi. Proto se dva jinak protichůdné procesy trestání a léčby v rostoucí míře propojují v moderním trestním právu, upřednostňujícím léčbu a rehabilitaci občanů, kteří se dostali do konfliktu se zákonem, před jejich jednostranným trestáním. Drogové soudy v USA, jež jsou největším zdrojem př́ilivu uživatelů drog do léčby, tak spolu s probačními instituty pro mládež a duševně choré rozšiřují foucaultovský panoptikon kontroly deviací v obyvatelstvu (Tiger 2008).
} 
k ničení sociálních vztahů uživatelů drog a k jejich sociálnímu vyčleňování. Jednotlivá opatření mohou mít navíc překvapivé vítěze a poražené: úspěšná policejní akce cílená na snížení dostupnosti kokainu může snížit rozsah jeho uživání, ale zároveň může zvýšit rozsah kriminality na trhu s kokainem a experimentování s alternativními drogami (MacCoun, Reuter a Schelling 1996). Představuje vyhranou bitvu v nekonečné válce s distributory, kterou nemohou distributoři prohrát, dokud bude po nelegálních drogách poptávka a „vyhrané“ bitvy budou zhoršovat podmínky pro zjednávání soukromé spravedlnosti v každodenních světech uživatelů drog.

Kvůli masovému pronikání drog mezi střední vrstvy, $\mathrm{k}$ němuž ve společnosti hojnosti dochází od 60. let 20. století, a v důsledku výrazného rozvoje lékařství se i v drogových politikách s rostoucí silou prosazuje medikalizace, tj. určení závislosti jako nemoci. Zodpovědnost za drogové problémy se tak umístuje podstatnou měrou mimo dosah jednotlivce (Acker 2002). Toto medicínské paradigma pomáhá minimalizovat obviňování závislých za jejich problémy. Protože trestní sankce jsou považovány za nespravedlivé, pokud aktéři nejsou schopni své činy kontrolovat (MacCoun 2003: 360), pomáhá medikalizace zmírňovat postihy závislých a alkoholiků, a jak již bylo naznačeno výše, může kompenzovat nežádoucí efekty trestní represe (k nezamýšleným důsledkům medikalizace se dostaneme v oddíle III).

Podobně jako se užívání drog stalo primárně lékařskou otázkou, také nejrůznější sociální handicapy a nespravedlnosti přecházely do pravomoci klinických psychologů, sociologů, sociálních pracovníků apod. a stávaly se objektem sociálních služeb nabízených sociální sítí rychle se rozvíjejícího welfare state. Popisovaná „welfarizace“ drogové náruživosti generovala závazky státu ne-li se př́mo starat o uživatele drog, tak alespoň v rámci solidarity financovat zdravotní i nezdravotní péči o ně.

Jaký je ale vliv různých opatření drogové politiky na řešení problémů meziosobní koordinace - a tedy i na soukromé zjednávání spravedlnosti - ve světech zahrnujících nekontrolující se uživatele drog? I když problém zjednodušíme na otázku vztahu mezi drogovou politikou a faktory neformální sociální kontroly a sebekontroly, máme o něm stále žalostně málo empirických informací, jestliže $\mathrm{v}$ to nepočítáme tragické př́iběhy nezvládání náruživosti a hroucení sociálních světů uživatelů drog (například MacCoun 1993). Moderní drogová politika o tomto koordinačním selhávání sociálních světů ví a snaží se přispívat k jeho řešení. Klade si za cíl obnovovat psychosociální fungování (mechanismus konstruování reality) uživatelů drog a usiluje výslovně o jejich sociální začleňování ve všech svých složkách - drogové prevenci, trestní represi i léčbě a sociální rehabilitaci uživatelů (Národní strategie 2005).

Klíčový koordinačně-spravedlnostní rozměr náruživosti (nezvládaná náruživost vede k porušování práv druhých osob a rozvrací vzájemnou koordinaci) ale stále více ustupuje ze zřetele, a do popředí se dostávají záležitosti zdravotního rizika a provozu trestního vymáhání práva. Domníváme se však, že primární důraz na uživatele drog s potřebou léčby nebo trestněprávní nápravy může vést $\mathrm{k}$ nedostatečnému důrazu veřejné politiky na typ „hraničního uživatele“, který má problémy se zvládáním náruživosti, ale doposud je začleněn do konvenčních sociálních rolí, a pomohla by mu některá z forem neléčebné intervence. V důsledku toho je soukromé zvládání drogové náruživosti u hraničních uživatelů neprávem zanedbáváno. Navíc, pro sisyfovský úkol léčby a sociální rehabilitace nekontrolujících se uživatelů drog není, stejně jako v oblasti trestní represe, zdrojů nikdy dost. Drogová politika tak podle našeho názoru 
sdílí, nejspíše nikoli náhodou, osud občanské a trestní spravedlnosti v posledních desetiletích, kde se navzdory rostoucím počtům žalob a s tím spojeným výdajům prístup ke spravedlnosti a kontrola zločinnosti zhoršovaly (viz napríklad Challenge of Crime in a Free Society 1967, Feucht a Zedlewski 2007, Zuckerman 2000).

\section{III}

Řada rodin utratí poslední cent, dům zastaví hypotékou, rozbije úspory na vysokou školu a na penzi, jak postupně zkouší různé programy drogové léčby. V mém případě byla většina nákladů na tyto programy hrazena ze zdravotního pojištění mého a jeho matky. Nejsem si jistý, co bychom bez tohoto pojistného krytí byli dělali. (Sheff 2005: 5)

\section{Výběrová tolerance náruživosti}

Představy, že drogový problém bude veřejnou politikou vyřešen bezezbytku, jsou uznávány jako utopické, jak ostatně naznačuje i redukční chápání národních strategií drogové politiky (snižování poptávky, snižování nabídky, snižování škod). Koordinační pojetí náruživosti přináší argumenty pro to, aby drogové politiky posilovaly obecné umění soukromého zvládání náruživosti, které uznává fakt, že náruživost $\mathrm{v}$ jistém smyslu patří $\mathrm{k}$ modernímu životu. Nabízíme novou optiku, nikoli převratné novinky v oblasti drogové prevence, léčby a sociální rehabilitace uživatelů. Tato optika ukládá, aby návrhy intervencí vycházely z předpokladu, že se budou utkávat s urputným „protivníkem“ náruživostí, která působí rozprostřeně a místně specificky. Zasahuje sociální světy $\mathrm{v}$ tom nejcitlivějším místě: deformuje mechanismus konstruování reality. Proto si tvưrci veřejné politiky, vědomi si jejích mezí, musejí klást realistické cíle a působit přiměřeně popsanému základnímu rozložení sil. Nejprve nabízenou optiku charakterizujeme nabídkou obecné strategie posilování umění zvládat náruživost. V následujícím oddílu reinterpretujeme metadonovou substituční léčbu jako veřejně politický zásah do drogové problematiky, který z hlediska předkládané teorie rozumně respektuje dílčí „bezmoc“ veřejných institucí při snižování poptávky v dané skupině.

\section{Umění zvládat náruživost jako drogová prevence}

Primární drogová prevence obvykle vychází z cílů odradit co největší počet mladých lidí od uživání drog anebo alespoň oddálit iniciaci jejich drogové kariéry do věku, kdy budou vůči drogám méně zranitelní. Obou cílů se dosahuje šířením poselství o škodlivosti a společenské nepríijatelnosti drog a zvyšováním atraktivity zdravého životního stylu bez drog (Bém a Kalina 2003). Hodně se diskutuje o tom, která opatření primární prevence jsou při plnění vytyčených cílů skutečně účinná a která jsou jen plýtváním veřejnými prostředky (například McGrath, Sumnall, McVeigh a Bellis 2007). Nevychází se z faktu, že děti a mladistvé ohrožují v dnešní společnosti hojnosti nejen drogy, ale i celá řada dalších náruživostí, a že zdroje tohoto rizika je nutné hledat $\mathrm{v}$ rolích, které náruživosti sehrávají v dynamických společnostech a v subkultuře mládeže. Málo pozornosti je též věnováno nezamýšleným důsledkům šiřených negativních 
poselství a podobně málo je diskutováno umění zvládat náruživosti společně s druhými lidmi a držet je pod kontrolou, tak aby život mladých spíše obohacovaly, než poškozovaly.

Pokud jde o samy mladistvé uživatele drog, byly primární prevence spolu s medikalizací kritizovány za to, že vytvářejí obraz užívání drog jako chorobného, nutkavého a sebedestruktivního chování (např́klad Hammersley a Reid 2002, Peele a Brodsky 1991, Harding 1998, Walters 1999, Davies 1997, Schaler 2000). Varovné výpovědi lékařù o ,pokročilých případech“, odstrašující protidrogové inzeráty nebo zážitkové akce typu „drogového vlaku“ předávají dětem zjednodušené poselství, že užívání drog vede k závislosti, ztrátě svobodné vůle a rozpadu fyzického a duševního zdraví. Takový obraz může mít nepříznivý dopad na sebepojetí uživatelů a způsobuje jejich symbolické „svazování“. Uživatelé jsou vedeni k vědomí vlastní bezmocnosti a to jim znemožňuje kontrolovat rizika užívání. Závislost se stává sebenaplňujícím se proroctvím, pokud uživatelé uvěří, že sami nemohou přestat, respektive mají k dispozici pádnou výmluvu ke vzdání se osobní odpovědnosti. Tato představa bezmocnosti legitimuje jejich parazitický životní styl a komplikuje léčebné úsilí (Morávek 2007a: 125-129).

Domníváme se, že bludný kruh představ o nekontrolovatelnosti užívání drog a nevyhnutelnosti scénářů rozvracejících každodenní světy uživatelů drog lze účinně mírnit, ne-li přetínat, vzděláváním a výcvikem uživatelů $\mathrm{k}$ umění zvládat náruživost a $\mathrm{k}$ účinné ochraně vlastních každodenních světů. Od takového působení, které bude založené na výkladu zranitelnosti každodenních světů vůči nezvládané náruživosti a na systematickém zavádění poznatků o rizicích a osobním managementu různých jednání, která se stávají předmětem náruživosti, užívání drog nevyjímaje, s důrazem na prevenci meziosobních konfliktů, si lze slibovat posílení odpovědnosti uživatelů a jejich sebekontroly (zplnomocnění). ${ }^{8}$ Tento směr v oblasti drogové prevence zastupují například programové práce Cohena (1999), Hathawaye (2001) a Duffa (2004) nebo nedávno do češtiny přeložená příručka pro rodiče od Marshy Rosenbaum (2008).

Drogová prevence by se v takovéto strategii musela vzdát výlučně „protidrogové“ rétoriky ve prospěch boje s širší škálou náruživostí a poselství šitých na míru různým skupinám mládeže. Znamenalo by to ovšem nejen radit mladým lidem, kteří již drogy pravidelně berou, jak je mohou užívat s mírou, ale také nechtěně schvalovat drogy těm, kteří s nimi začínají experimentovat. To staví tvưrce politiky před politické dilema, které samozřejmě teoreticky řešitelné není.

\section{Metadonová substituční léčba anebo kontrolované užívání drog}

V prvním prŕikladu jsme se věnovali opatřením drogové politiky, která mají za úkol zabránit vzniku nezvládaných náruživostí. Šance, že by tytéž metody mohly pomoci většímu počtu

8 Filosofie posílení odpovědnosti uživatelů a jejich sebekontroly (zplnomocnění) má dobře známou analogii v boji s chronickými nemocemi (Barlow a kol. 2002). Úspěšně je např́ílad užívaná právě u adolescentů odpoutávajících se z dětské závislosti na rodičích. Mladí astmatici mohou záchvaty dušnosti mocensky využívat vůči rodičům, kteří dosud nesli odpovědnost za průběh onemocnění, bohužel tak zároveň dále zabředávají do nemoci. Metafora přirovnávající rízení nemoci $\mathrm{k}$ rrízení auta umožnila nabízet mladistvým astmatikům velmi úspěšně výcvik ve zvládání nemoci. 
uživatelů již chronicky ,propadlých“ drogám, nejsou velké. Ve vhodných př́ípadech jsou proto dlouhodobě závislým zpřístupňovány drogy v kontrolované podobě.

Metadonová substituční léčba závislosti na opioidech (MSL; např́iklad Brands, Marsh, Hart a Jamieson 2002) udržuje symbolické odmítání drogy (prohibici), nebot’ předepisován není přímo heroin/droga, nýbrž náhradní metadon/léčivo. Lze ji nicméně považovat za veřejně politický zásah do drogové problematiky, který respektuje dílčí „bezmoc“ veřejných institucí při snižování poptávky v dané skupině. Pro náš výklad je pak MSL zajímavá též tím, že obnovuje fungování soukromého zjednávání spravedlnosti, a tak dosahuje jinak nedostupných příznivých efektů v oblasti širokého spektra škod vázaných na koordinaci uživatelů drog s jejich sociálním okolím.

Poskytnutí substituční drogy osobám s dlouhodobou závislostí na heroinu vede k řadě př́znivých efektů: pokles objemu spotřebovaného heroinu (Hall a kol. 1998: 53), pokles spotřeby alkoholu a jiných drog (NIDA 1995: 4-15), zlepšení v oblasti fyzického a duševního zdraví, sociálního fungování (Fletcher a Battjes 1999: 85), kvality života (Dazord, Mino, Page a Broers 1998) a psychické pohody (Dole, Nyswander a Kreek 1966). V rovině sociální metadon pomáhá odstranit hlavní nezamýšlený důsledek drogové prohibice - trestnou činnost motivovanou opatřením drogy nebo prostředků na její nákup (Fletcher a Battjes 1999: 85, Hall et al. 1998: 53, Zábranský 2004: 159). Jak se zpomaluje a zastavuje divoce roztočený drogově-akviziční kolotoč, získává uživatel čas a prostor uspořádat si život znovu podle svého. MSL prokazatelně vede ke zlepšení spolehlivosti ve škole či zaměstnání, nápravě rodinných a osobních vztahů a získání či zlepšení bydlení, zlepšení zaměstnanosti (Wolff 2006: 572) a zvýšení legálních pracovních výdělků (National Consensus Development Panel 1998: 1939). Počet „sociálně produktivních“ - zaměstnaných, studujících nebo pečujících o domácnost - v jedné studii MSL vzrostl po dvou letech z 36 \% na 76 \% (Gearing a Schweitzer 1974). Všechny tyto výzkumně prokázané př́iznivé efekty nasvědčují hypotéze, že regulovaný přísun metadonu obnovuje sensitivitu uživatelů vůči praktikám soukromého vymáhání spravedlnosti, dřive vyřazovanou ze hry náruživostí. Díky zvyšování spolehlivosti, návratu do konvenčních rolí a odbourávání stigmatu se ovšem také obnovuje mechanismus konstruování reality.

Studie, zaměřené na uživatele drog, většinou nehovoří o tom, že zbavují druhotných důsledků náruživosti také osoby blízké. Nikův otec, který ji vyjádřil výše citovaným výrokem: „stal jsem se závislým na závislosti mého dítěte“, bohužel nemůže doufat ve spásu skrze metadon, ten totiž pomáhá jen primárním uživatelům heroinu a dalších opioidů. Výzkum a vývoj substituční terapie pro lidi závislé na stimulačních drogách je teprve v začátcích (Rothman, Blough a Baumann 2006).

\section{Závěr}

V tomto článku jsme řešili otázku, jaké následky má nezvládaná drogová náruživost pro konstruování reality v souvislosti se selháváním soukromého zjednávání spravedlnosti, a tím i vzájemné koordinace v každodenních světech uživatelů. Možnosti drogových politik rozetnout tento povýtce do mikrosvětů situovaný bludný kruh opakovaně se hroutící naděje, závislosti, vzájemného poškozování a vylučování jsou z pohledu koordinačního pojetí zvládání náruživosti velmi omezené. Je tomu tak proto, že tento bludný kruh - jako v Nikově př́padu 
- zmarňuje životy nejen uživatelů drog, ale i osob jim blízkých. Zhroucení meziosobní koordinace mezi nekontrolujícími se uživateli drog a ostatními účastníky kvưli nespolehlivosti, zanedbávání povinností, porušování dohod, neplnění slibů, podvodům, krádežím, ale také fyzickému i morálnímu úpadku se stává rozhodující překážkou pro vnášení raádu do života účastníků drogového dění. Náprava proto může být také jen situovaná a provedená týmiž účastníky drogového dění.

Veřejná politika může účinně zasahovat do takto ohrožovaných každodenních světů zpravidla jen nepřímo, vytvářením podmínek pro soukromý boj s náruživostí. To ovšem také znamená, že drogové politiky se mohou nezamýšleně, svými vedlejšími účinky, stát samy součástí bludného kruhu. Účinná obrana vůči popisované deformaci spočívá v tom, že drogové politiky rozšliři svůj obzor z problémových uživatelů drog i na jejich problémové transakce se sociálním okolím a budou skládat účty také z toho, jak přispívají k udržování a znovunastolování soukromého zjednávání spravedlnosti v každodenních vztazích. V nutných př́ípadech pak ovšem tento př́stup povede tvůrce politiky také $\mathrm{k}$ tomu, aby moudře tolerovali kontrolované užívání drog podporou umění zvládat náruživost anebo nabídkou substituční léčby.

Uživatelé nelegálních drog dostávají v současné době od tvưrců drogové politiky signály o drogách zejména ústy zástupců policie a soudů („drogy jsou špatné a jejich užívání vede ke konfliktu se zákonem“), primární prevence (,drogy jsou nebezpečné, užívání vede ke ztrátě sebekontroly, poškození zdraví a životnímu rozvratu“) a pomáhajících profesí („,v prípadě problémů budete potřebovat formální léčbu“). Méně sledovanou linií je podpora neformální kontroly drog, která by uživatelům drog sdělila: „Holdování jakýmkoliv náruživostem je nejen inspirující, ale také nebezpečné. Pokud se přesto rozhodnete např́ílad užívat drogy, poučte se o rizicích a drogu užívejte s mírou a s ohledem na své závazky. Držte svou náruživost na uzdě, pomáhejte s tím i druhým, vyvarujte se rizikového sociálního prostředí.“

Vrat'me se ale na obecnější úroveň. Je zřejmé, že vláda se svými omezenými prostředky na provoz trestního systému a léčbu by měla mít za cíl především to, aby občané její zásahy vůbec nepotřebovali. Preventivní sdělení by proto měla zejména mládež více zplnomocňovat a imunizovat vi̊či nezdrženlivosti nejen drogové. Chce-li stát účinně zajištovat zjednávání spravedlnosti, musí mít občané svůj život pod kontrolou a i bez vnějšího donucení činit zpravidla zodpovědné volby v každodenních záležitostech, at' čelí pokušením adrenalinových sportů, sexu, herních automatů, drog, anebo i práce.

Opatření léčby a sociální rehabilitace, spjatá s veřejnou podporou zvládání náruživostí, se mohou právem dovolávat solidarity s trpícími, chudými a chorobnými, ale tato dikce nemůže odradit část veřejnosti a politiků od toho, aby ji nepovažovali za nemravnou pomoc pachatelům, která navíc staví stát do role jejich tichého společníka. Obě výše uvažovaná opatření můžeme však odůvodnit nejen solidaritou, nýbrž i ochranou práv občanů. Lidé smíření s rolí stigmatizovaného, sociálně vyloučeného a nekontrolujícího se uživatele drog anebo gamblera, získávající zdroje z kriminálních činností, představují jedno z největších rizik pro tato práva. A naopak, jedině při zakotvení $\mathrm{v}$ konvenčních sociálních rolích a vazbách - a při současném důrazu na udržení náruživosti pod kontrolou - mohou současní nebo bývalí „náruživci“ fungovat jako v zásadě spolehliví partneři v každodenních situacích na poli rodiny, partnerských vztahů, školy, zaměstnání atd. 
Zbývá pak už jen jediná vážná námitka proti strategii výběrové tolerance náruživosti a ta je stejná jako v př́padě často diskutované legalizace měkkých drog: jaké by byly bezprostřední a dlouhodobé účinky měkčího přístupu na vývoj prevalence nezvládání takové náruživosti? Do jaké míry by například měkké drogy následovaly špatný příklad alkoholu a cigaret a s nimi spojených škod? Protože společenské vědy v této oblasti nejsou schopny nabídnout žádné kvalifikované odhady možného vývoje - jedná se o problém ovlivňovaný mnoha vzájemně se podmiňujícími činiteli - činí tato prorocká námitka otázku volby strategie otázkou hodnotovou a politickou. Předložené teoretické argumenty, odhalující meze politik vypořádávajících se s náruživostmi, dané jejich důsledky pro ne/fungování soukromých světů uživatelů drog, se v této souvislosti jeví jako naléhavé upozornění, že žijeme v dynamickém světě, kde samotné vlády bez zapojení zúčastněných osob mohou svými politikami řídit vývoj lidských náruživostí, asi tak jako mohou poroučet větru a dešti. Tam, kde předstírají, že mohou vymýtit, co se vymýtit nedá, tam se jejich opatření automaticky stávají dvojznačně působící součástí řešeného problému. Proto je asi moudré, že vlády poskytují uživatelům drog „měkká“ opatření jako metadonovou substituční léčbu. Rovněž pak považujeme za moudré, aby vládní politiky přiměřeně věku hojnosti podporovaly rozvoj kultury zvládání náruživostí a sebeovládání. Nedílnou součástí takového přístupu je ovšem též vědomí, že černobílý pohled na drogy je neprosaditelný, zejména v subkulturách mládeže. Občané mohou drogy a jiné formy holdování náruživostem s vědomím prŕíslušných rizik zahrnout do svého životního stylu, což se také s větší či menší prevalencí běžně děje. Důležité proto je, aby tito občané rozvíjeli sebepoznání v oblasti zvládání potíží, stresu i náruživostí a osvojili si určité zásady a dovednosti, které obecně redukují rizikovost holdování náruživostem. V neposlední řadě je důležitou dovedností i umění přesvědčit o své trvající důvěryhodnosti a férovosti svými činy druhé.

\section{Literatura}

ACKER, Jean Caroline. Creating the American Junkie : Addiction Research in the Classical Era of Narcotic Control. Baltimore : Johns Hopkins University Press, 2002. 288 s. ISBN 0-801-88383-0.

APA. Diagnostic and Statistical Manual of Mental Disorders (DSM-IV). 4. vyd. Washington, DC : American Psychiatric Association, 1994. 886 s. ISBN 0-890-42062-9.

BARLOW, Julie ; WRIGHT, Chris ; SHEASBY, Janice ; TURNER, Andy ; HAINSWORTH, Jenny. SelfManagement Approaches for People with Chronic Conditions : A Review. Patient Education and Counseling, 2002, roč. 48, č. 2, s. 177 - 187. ISSN 0738-3991.

BÉM, Pavel ; KALINA, Kamil. Úvod do primární prevence : východiska, základní pojmy a přístupy. In KALINA, K., RADIMECKÝ, J. (eds.). Drogy a drogové závislosti 1: Mezioborový př́stup. Praha : Úřad vlády ČR, 2003, s. 274 - 283. ISBN 80-867-3405-6.

BERTRAM, Eva ; BLACHMAN, Morris ; SHARPE, Kenneth ; ANDREAS, Peter. Drug War Politics : The Price of Denial. Berkeley, CA : University of California Press, 1996. 347 s. ISBN 0-520-20598-7.

BOERI, Miriam Williams ; STERK, Claire E. ; ELIFSON, Kirk W. Baby Boomer Drug Users : Career Phases, Social Control and Social Learning Theory. Sociological Inquiry, 2006, roč. 76, č. 2, s. 264 - 291. ISSN 0038-0245.

BRANDS, Bruna ; MARSH, David ; HART JAMIESON, Liz. Literature Review : Methadone Maintenance Treatment [online]. Ottawa : Office of Canada's Drug Strategy, Health Canada, 2002. 86 s. 
ISBN 0-66231-596-0. [cit. 2009-06-08]. Dostupné na : <http:/www.hc-sc.gc.ca/hl-vs/alt_formats/ hecs-sesc/pdf/pubs/adp-apd/methadone/litreview_methadone_maint_treat.pdf $>$.

BROOK, Heather ; STRINGER, Rebecca. Users, Using, Used : A Beginner's Guide to Deconstructing Drugs Discourse. International Journal of Drug Policy, 1995, roč. 16, č. 5, s. 316 - 325. ISSN 0955-3959.

The Challenge of Crime in a Free Society : A Report By The President's Commission On Law Enforcement and Administration of Justice. Washington : U.S. Government Printing Office, 1967. 340 s.

COHEN, Peter. Shifting the Main Purposes of Drug Control : From Suppression to Regulation of Use : Reduction of Risks as the New Focus for Drug Policy. International Journal of Drug Policy, 1999, roč. 10, č. 3, s. 223 - 234. ISSN 0955-3959.

COPELLO, Alex; ORFORD, Jim. Addiction and the Family : Is it Time for Services to take Notice of the Evidence? Addiction, 2002, roč. 97, č. 11, s. 1361 - 1363. ISSN 0965-2140.

DAVIES, John Booth. Drugspeak: The Analysis of Drug Discourse. Amsterdam : Harwood Academic Publishers, 1997. 195 s. ISBN 9-05702-191-9.

DAZORD, Alice ; MINO, A. ; PAGE, D. ; BROERS, B. Patients on Methadone Maintenance Treatment in Geneva. European Psychiatry, 1998, roč. 13, č. 5, s. 235 - 241. ISSN 0924-9338.

DENNING, Patt ; LITTLE, Jeannie ; GLICKMAN, Adina. Over the Influence: The Harm Reduction Guide for Managing Drugs and Alcohol. New York: The Guilford Press, 2004. 328 s. ISBN 1-57230-800-1.

DOLE, Vincent P. ; NYSWANDER, Marie E. ; KREEK, Mary Jeanne. Narcotic blockade. Archives of Internal Medicine, 1966, roč. 118, č. 4, s. 304 c 309. ISSN 0003-9926.

DUFF, Cameron. Drug Use as a 'Practice of the Self': Is there any Place for an 'Ethics of Moderation' in Contemporary Drug Policy? International Journal of Drug Policy, 2004, roč. 15, č. 5-6, s. 385 - 393. ISSN 0955-3959.

EIU. Supporting Families and Carers of Drug Users : A Review [online]. Edinburgh : The Scottish Executive Effective Interventions Unit, 2002. 102 s. [cit. 2009-06-08]. Dostupné na: $<$ http://www. scotland.gov.uk/Resource/Doc/47007/0025628.pdf>.

EMCDDA. Number of Opioid Maintenance Treatment Clients as Rate Per 100 of the Estimated Number of Problem Opioid Users, 2005-06 [online]. EMCDDA Statistical Bulletin. Lisabon : Evropské monitorovací středisko pro drogy a drogovou závislost, 2007. [cit. 2009-06-08]. Dostupné na: <http:// www.emcdda.europa.eu/stats08/hsrfig1>.

FLETCHER, Bennett W. ; BATTJES, Robert J. Introduction to the Special Issue : Treatment Process in DATOS. Drug and Alcohol Dependence, 1999, roč. 57, č. 2, s. 81 - 87. ISSN 0376-8716.

FEUCHT, Thomas E. ; ZEDLEWSKI, Edwin. The 40th Anniversary of the Crime Report. NIJ Journal [online], 2007, č. 257. [cit. 2009-06-08]. Dostupné na: <http://www.ojp.usdoj.gov/nij/ journals/257/40th-crime-report.html $>$.

GARFINKEL, Harold. Studies in Ethnomethodology. Englewood Cliffs : Prentice Hall, 1967. 288 s. ISBN 0-13858-381-1.

GEARING, Frances Rowe ; SCHWEITZER, Morton D. An Epidemiologic Evaluation of Long-Term Methadone Maintenance Treatment for Heroin Addiction. American Journal of Epidemiology, 1974, roč. 100, č. 2, s. $101-112$. ISSN 0002-9262.

GUSFIELD, Joseph. Constructing the Ownership of Social Problems : Fun and Profit in the Welfare State. Social Problems, 1989, roč. 36, č. 5, s. 431 - 441. ISSN 0037-7791.

GUY, Philip. Bereavement Through Drug Use : Messages from Research. Practice : Social Work in Action, 2004, roč. 16, č. 1, s. 43 - 54. ISSN 0950-3153.

HALL Wayne ; WARD, Jeff ; MATTICK, Richard P. The Effectiveness of Methadone Maintenance Treatment 1: Heroin Use and Crime. In WARD, J., MATTICK, R. P., HALL, W. (eds.). Methadone 
Maintenance Treatment and Other Opioid Replacement Therapies. Amsterdam : Overseas Publishers Association, Harwood Academic Publishers, 1998, s. 17 - 57. 480 s. ISBN 9-05702-239-7.

HAMMERSLEY, Richard; REID, Marie. Why the Pervasive Addiction Myth is Still Believed. Addiction Research \& Theory, 2002, roč. 10, č. 1, s. 7 - 30. ISSN 1606-6359.

HARDING, Wayen M. Informal Social Controls and the Liberalization of Drug Laws and Policies. In COOMBER, R. (ed.). The Control of Drugs and Drug Users : Reason or Reaction? Amsterdam: Harwood Academic Publishers, 1998, s. 213 - 231. ISBN 9-05702-188-9.

HARTNOLL, Richard. Drogy a drogové závislosti : Propojování výzkumu, politiky a praxe. [online]. Praha : Úřad vlády ČR, 2005. 96 s. ISBN 9057021889. [cit. 2009-06-08]. Dostupné na: <http://www. drogy-info.cz/index.php/publikace/monografie/hartnoll_drogy_a_drogova_zavislost>.

HATHAWAY, Andrew D. Shortcomings of Harm Reduction : Toward a Morally Invested Drug Reform Strategy. International Journal of Drug Policy, 2001, roč. 12, č. 2, s. 125 - 137. ISSN 0955-3959.

HENRY, Stuart. Private Justice : Towards Integrated Theorising in the Sociology of Law. London : Routledge, 1983. 256 s. ISBN 0-71009-703-4.

HURWICZ, Leonid. Institutions as Families of Game Forms. Japanese Economic Review, 1996, roč. 47, č. 2, s. 113 - 132. ISSN 1352-4739.

HUSAK, Douglas N. The Moral Relevance of Addiction. Substance Use \& Misuse, 2004, roč. 39, č. 3, s. 399 - 436. ISSN 1082-6084.

JOSEPHSON, John R.; JOSEPHSON, Susan G. Abductive Inference : Computation, Philosophy, Technology. Cambridge : Press Syndicate of the University of Cambridge, 1996. 320 s. ISBN 0-52157-545-1.

KABELE, Jiří. Přerody - principy sociálního konstruování. 1. vyd. Praha : Karolinum, 1998. 396 s. ISBN 80-718-4359-8.

KABELE, Jiří. Z kapitalismu do socialismu a zpět. 1. vyd. Praha : Karolinum, 2005. 584 s. ISBN 80-246-1127-9.

KABELE, Jiří. Sociální koordinace a spravedlnost. In HÁJEK, M. (ed.). Praktiky ne/spravedlnosti : pojmy, slova, diskurzy. Praha : Matfyzpress, 2007, s. 79 - 98. ISBN 978-80-737-8035-7.

KABELE, Jiří. Czech and Slovak Civil/Criminal Justice and the Protection of Constitutionality. In POTƯČEK, M. (ed.). Capacities of Governance in the Czech Republic. Praha : Matfyzpress, 2008, s. 77 - 108. ISBN 978-8-07378-038-8.

KABELE, Jiří. Agency/Structure Dilemma : A Coordination Approach. Journal for the Theory of Social Behaviour. [v tisku].

KLEIMAN, Mark. Coerced Abstinence : A Neo-Paternalist Drug Policy Initiative. In MEAD, L. (ed.). The New Paternalism : Supervisory Approaches to Poverty. Washington : Brookings Institution Press, 1997, s. 182 - 219. 355 s. ISBN 0-81575-651-4.

KUDA, Aleš. Následná péče jako klíčový faktor v systému léčby závislostí. Adiktologie, 2006, roč. 1, č. 2, s. 82 Working with Drug Family Support Groups 93. ISSN 1213-3841.

LOCKLEY, Paul. Working with Drug Family Support Groups. London : Free Association Books, 1996. 266 s. ISBN 1-85343-336-8.

LUCKMANN, T. Shrinking Transcendence, Expanding Religion? Sociological Analysis, 1990, roč. 51, č. 2, s. 127 - 138. ISSN 1097-7147.

MACCOUN, Robert. Is the Addiction Concept Useful for Drug Policy? In VUCHINICH, R., HEATHER, N. (eds.). Choice, Behavioural Economics and Addiction. Oxford : Elsevier Science, 2003, s. $355-378$. ISBN 0-08044-056-9.

MACCOUN, Robert. Drugs and the Law : A Psychological Analysis of Drug Prohibition. Psychological Bulletin, 1993, č. 113, 497 - 512. ISSN 0033-2909.

MACCOUN, Robert ; REUTER, Peter ; SCHELling, Thomas. Assessing Alternative Drug Control Regimes. Journal of Policy Analysis and Management, 1996, roč. 15 , č. 3, s. 330 - 352. ISSN 0276-8739. 
MCCAMBRIDGE, JIM ; STRANG, John. Patterns of Drug Use in a Sample of 200 Young Drug Users in London. Drugs : Education, Prevention, and Policy, 2004, roč. 11, č. 2, s. $101-112$. ISSN 0968-7637.

MCGRATH, Yuko ; SUMNALL, Harry ; MCVEIGH, Jim ; BELLIS, Mark. Prevence užívání drog mezi mladými lidmi : Přehled dostupných informací. [online]. Praha : Úřad Vlády ČR, 2007. $72 \mathrm{~s}$. ISBN 978-80-8704-116-1. [cit. 2009-06-08]. Dostupné na: <http://www.drogy-info.cz/index.php/ content/download/44451/200788/file/prevence_uzivani_drog_mezi_mladezi_web.pdf $>$.

MORÁVEK, Jan. Definování problému v drogové politice : konstrukce nezákonných drog a jejich uživatelů ve věděni expertů [nepublikovaná disertační práce]. Praha : FSV UK, 2007[a].

MORÁVEK, Jan. Kontrolované užíání drog : co nám přináší výzkum uživatelů, kteří s drogami umějí zacházet. Adiktologie, 2007[b], roč. 7, č. 4, 445 - 455. ISSN 1213-3841.

MORÁVEK, Jan. Ten Years After ,Bigger than Small': Structuring the Problem in Czech Drug Policy 1998. Central European Journal of Public Policy, 2007[c], roč. 1, č. 1, s. 48 - 63. ISSN 1802-4866.

Národni strategie protidrogové politiky na obdobi 2005-2009. [online]. Praha : Úřad vlády ČR, 2005. 31 s. ISBN 80-8673-439-0. [cit. 2009-06-08]. Dostupné na: <http:/www.vlada.cz/assets/ppov/ protidrogova-politika/dokumenty/publikace/Strategie_05-09_CZ_web.pdf $>$.

National Consensus Development Panel on Effective Medical Treatment of Opiate Addiction. Effective Medical Treatment of Opiate Addiction. Journal of the American Medical Association, 1998, roč. 280, č. 22, s. 1936 - 1943. ISSN 0002-9955.

NIDA. Methadone Maintenance Treatment : Translating Research into Policy. Bethesda, MD : National Institute on Drug Abuse, 1995.

NÓTÁRI, Tamás. The Scales as the Symbol of Justice in the Iliad. Acta Juridica Hungarica, 2005, roč. 46, č. 3-4, s. 249 - 259. ISSN 1216-2574.

PEELE, Stanton ; BRODSKY, Archie. The Truth about Addiction and Recovery. 1. vyd. New York : Fireside, 1991. 432 s. ISBN 0-67175-530-0.

QUIGLEY, Paul. Family and Community Burdens of Addiction : Case-Mix Analysis at a new Community-Based Methadone Treatment. Drugs : Education, Prevention and Policy, 2002, roč. 9, č. 3, s. 221 - 231. ISSN 0968-7637.

ROSENBAUM, Marsha. Bezpečnost především : realistický př́stup $k$ dospívajícím a drogám. Praha : Magistrát hl. m. Prahy a Centrum adiktologie Psychiatrické kliniky 1. LF UK, 2008. [cit. 2010-03-07]. Dostupné na: <http://www.adiktologie.cz/download/1760/bezpecnost-predevsim-web.pdf>.

ROTHMAN, Richard B ; BLOUGH, Bruce E; BAUMANN, Michael H. Appetite Suppressants as Agonist Substitution Therapies for Stimulant Dependence. Annals of the New York Academy of Sciences, 2006, roč. 965, s. 109 - 126. ISSN 0077-8923.

SAMHSA. Results from the 2005 National Survey on Drug Use and Health : National Findings [online]. 2006, 267 s. Washington, DC : Department of Health and Human Services, Substance Abuse and Mental Health Services Administration [cit. 2009-06-08]. Dostupné na: <http://oas.samhsa.gov/ nsduh/2k5nsduh/2k5results.pdf $>$.

SCHALER, Jeffrey A. Addiction Is a Choice. Chicago : Open Court, 2000. 179 s. ISBN 0-81269-404-8.

SHEFF, David. My addicted son. New York Times Magazine [online], 2005. [cit. 2009-06-08]. Dostupné na: <http://www.nytimes.com/2005/02/06/magazine/06ADDICT.html>.

SHEFF, David. Beautiful Boy : A Father's Journey through His Son's Addiction. Boston : Houghton Mifflin, 2008. 326 s. ISBN 0-61868-335-2.

TIGER, Rebecca. Drug Courts and Coerced Treatment : The Social Construction of „Enlightened Coercion “. New York : City University of New York, 2008. [Nepublikovaná disertační práce].

VELLEMAN, Richard ; BENNETT, Gerald ; MILLER, Tony ; ORFORD, Jim ; RIGBY, Kate ; TOD, Anne. The Families of Problem Drug Users: The Accounts of Fifty Close Relatives. Addiction, 1993, roč. 88, č. 9, s. 1281 - 1289. ISSN 0965-2140. 
WALTERS, Glenn D. The Addiction Concept : Working Hypothesis or Self-Fulfilling Prophesy? 1. vyd. Boston : Allyn \& Bacon, 1999. 273 s. ISBN 0-20528-642-3.

WEBER, Max. Protestantská etika a duch kapitalismu. In WEBER, M. Metodologie, sociologie a politika. 1. vyd. Praha : OIKOYMENH, 1998, s. 185 - 226. ISBN 80-8600-548-8.

WHO. The International Statistical Classification of Diseases and Health Related Problems, Tenth Revision (ICD-10). Volume 1: Tabular List. Ženeva : Světová zdravotnická organizace, 1990. $1196 \mathrm{~s}$. ISBN 9-24154-649-2.

WOLFF, Kim. Substitute Prescribing. In KARCH, S. (ed.). Drug Abuse Handbook. 2. vyd. London : CRC Press, 2006, s. 566 - 572. ISBN 0-84931-690-6.

ZÁBRANSKÝ, Tomáš. Přehled odborných článků na téma evaluace substituční (udržovací) léčby na bázi metadonu. Adiktologie, 2004, roč. 4, č. 2, s. 157 - 163. ISSN 1213-3841.

ZUCKERMAN, Adrian A. S. Reforming Civil Justice Systems : Trends in Industrial Countries [online]. PREM Notes, 46 (ř́ijen 2000). Washington : Světová banka, 2000. [cit. 2009-06-08]. Dostupné na: $<$ http://www1.worldbank.org/prem/PREMNotes/premnote46.pdf>.

\section{Autor̆i}

Jiří Kabele je profesorem sociologie na Fakultě sociálních věd Univerzity Karlovy v Praze. Zabývá se sociální dynamikou, transitologií, ekonomickou sociologií, sociologií práva a institucionální analýzou. V současné době rozpracovává a zahraniční odborné veřejnosti prezentuje vybrané součásti své teorie duální sociální konstrukce reality: koordinační řešení dilematu jednání a struktur, ekonomii neurčitosti atd.

Kontakt: jiri.kabele@volny.cz.

Jan Morávek působí jako vědecký pracovník v Institutu sociologických studií Fakulty sociálních věd Univerzity Karlovy v Praze. Zajímá se o definování problému v drogových politikách, kontrolované užívání drog, průsečíky drog se spravedlností a kvalitativní metody sociálního výzkumu.

Kontakt: www.jan-moravek.cz, jan.moravek@gmail.com. 